\title{
Using video footage to analyze students' arguments in solving exercises: an experience in basic education
}

\author{
Terezinha Marisa Ribeiro de Oliveira (iD https://orcid.org/0000-0002-9064-8518 \\ Universidade Cruzeiro do Sul \\ E-mail: terezinha.marisa@gmail.com
}

Carmem Lúcia Costa Amaral (iD https://orcid.org/0000-0002-6495-153X

Universidade Cruzeiro do Sul

E-mail: carmem.amaral@cruzeirodosul.edu.br

\begin{abstract}
The aim of this paper is to describe the qualitative research in which we used video footage as a didactic resource to understand students' arguments and justifications in solving mathematical problems. Participated in this study 28 students from the 9th grade of the school within in São Paulo (Brazil). For the analysis of the students' arguments, we used as reference the authors D'Ambrósio (2001), Orlandi (2009) and Sadovsky (2010). The results showed that video footage can be a resource to be explored by teachers to analyze not only their students' arguments and justifications in solving problems, but also to aid the teachers to self-assessment of your teaching practices.
\end{abstract}

\section{Keywords: Learning. Basic education. Video recording.}

\section{Introduction}

School is the place where the student goes to learn, and the teacher, to teach, since it is a distinct space that needs to evolve quickly, so it will not lose its identity. According to Tardif (2012), when keeping the students physically inside the classroom, they may not be obligated to participate in a established script for their learning, although some tasks must be performed. However, the students must be stimulated to be willing to be part of the teaching process in which they are included. Behrens (2006) suggests that, in order to break the traditional class conservatism, the teacher must consider the language in different ways, besides the oral and written ones; digital language should be part of the teaching repertoire as well.

Hence, Moran (1995), Masetto (2006), Borba and Oechsler (2018) propose the appreciation of the technology usage as a teaching strategy. Technology has transformed the teacher-student relation, and also the teaching-learning process. For instance, one of the resources used by North-American Universities is the video footage, which provides a broad experience in this area way ahead the Brazilian Universities (POWELL; SILVA, 2015).

However, Brazilian researchers have been interested in using the video footage method with the internet in their researches. This can leverage use and acknowledgment of this resource by the Education professionals (BORBA; OECHSLER, 2018). 
Encouragement for this resource to be used by teachers is in what the student reads and views, because his/her speech is developed mostly due to the visual sensation, rather than the rationality. Therefore, audiovisual language creates multiple perceptive attitudes, because it uses the imagination as a mediation role for affection, which is fundamental nowadays, since the written language develops a more strict and organized structure, besides the logic analysis (MORAN,1995).

This paper presents a research that aims at understanding how the video footage can be used by the teacher as a resource for comprehending the students' arguments and justifications when solving the exercises, and also for checking, through the students' language, if the instructions remain the focus within the education context.

\section{Use of video footage in school environments}

The use of footage in school environments is not much disseminated in Brazil, unlike Universities of developed countries. As a consequence, the study of videos by Brazilian researchers is not an usual practice in our academic environment; we still have only a few papers that address this subject, and that propose this method as a teaching resource to study the way the students elaborate their exercises' resolution (POWELL; SILVA, 2015).

One reason for the limitation of this resource can also be connected to ethical issues. We must refer to the Child and Adolescent Statute (ECA), which holds rules that limit such usages. We may not forget that the increasing technology wave causes concerns regarding the use of images produced when institutions and the human being, in general, are involved.

In relation to this, Kramer (2002) concerns about the indiscriminate and abusive use of children's image, and even if it is used for researches, there is no way to dam the seduction it has on the researchers themselves. However, the doubt still remains regarding this indiscriminate and free contribution of the images' use by the researcher.

Footage of the school environment by teachers may compose a personal material of work and research, including a more detailed study of the activities, enabling the document of the most important subject at that point. This activity carried out by the teacher might not be used promptly, but it can be a research source at other opportunities, as the content is developed during the education journey (POWELL; SILVA, 2015).

The relation established among teacher, video and students must always be linked to a document resource. Therefore, the footage of the school environment as the first possibility is used as a record of what has been performed in the classroom. As a documented evidence, such material is lost at the end of the school year, becoming useless.

Meanwhile, using the footage aims not only at being a documented evidence or record, but it can also represent a research about learning, or to express mathematical ideas, in this case, which can be oral, written or through gestures (BORBA; OECHSLER, 2018), and even be part of a school collection for studying the cognitive process.

According to Demo (2010a), the teacher is not expected to become a professional researcher, but instead, to learn how to do it, in order to become a professional researcher in their own department, considering the research as a capacitor of 
knowing how to think, and of including the educational power. Although this is important, in Brazil, there is a lack of literature of the video footage as a study instrument of teachers and researchers, in order to observe the students' thoughts when solving the problems.

Therefore, the video is an educational resource, and it can be used as part of a research, which can be an instrument for assessment, either of the school process as a whole, or of its parts (MORAN, 1995).

Moran (1995) states that the video can understand the body language, or even help teachers to see themselves in the work environment performing their role. So, he classifies the self-video as a way to monitor the behavior, or as a resource to encourage the shiest students to participate, and to make the outgoing ones give some space.

For that matter, technology must not be ignored in learning processes, since the footage of classes can be a great allay, if well structured. Moran (2015) points out that activities and challenges might be supported by technology for monitoring and assessing, but he also warns that this must be well planned, in order to be able to achieve the intended skills, such as intellectual, emotional, personal and communication capacities. For this to happen, when suggesting activities and challenges, the teacher must instruct the student to search and to understand different points of view from the discovery, and then go from the simplest to the most complex.

Demo (2010a) emphasizes the importance of the research for teaching. He believes that the teacher, when focusing on the class, and not on the learning, does not produce knowledge, but exposes it instead. The actual class is the one that reflects the process of knowledge production, which brings to light new awareness or reconstructs it. Thus, it is good to have classes with researchers, since producing knowledge has nothing to do with disruption that marks knowledge.

That line of thinking is important, since it is an instrument that allows the researcher to understand how students create their solutions. Garcez, Duarte and Heisenberg (2011) indicates the need of getting acquainted with the object of research, which helps to better understand the matter under study, producing reliable records.

In this respect, Sadalla and Larocca (2004) use the autoscopy as a technical resource that uses the video footage for analysis and reflection. This process aims at learning about the actions performed by the actors or by the person under discussion, through their speeches, and the images recorded. For both authors, the autoscopy may be used in different situations, like in learning or in teachers' education. However, they warn that "the functioning of analysis through the video is not an easy task to carry out"1 (SADALLA; LAROCCA, 2004, p. 422, our translation).

In order to perform the video footage, it is necessary to consider multiple aspects, such as the researcher's view. According to Honorato et al. (2006), and Powell, Francisco and Maher (2004), the video footage is likely to reduce the researcher contribution, so it allows to capture more angles from a certain reality.

Therefore, the view is not eliminated, since there is always the view from the person who records the video, even if he/she is not the researcher, but responsible for the act, so this person is considered the co-author. This view is not neutral, because the

1 "o funcionamento de uma análise através do recurso do vídeo não é tarefa fácil para se realizar" 
co-author limit the scenes, he/she considers important when choosing the images (HONORATO et al., 2006).

Garcez, Duarte e Eisenberg (2011) address the technical aspects about capturing and editing images, and explain that, with technology advance, handling digital cameras is easy, even though they are considered sophisticated resources to a certain level; however, they believe it is necessary to become acquainted with the equipment.

According to Sadalla and Larocca (2004), and Garcez, Duarte and Eisenberg (2011), it is pretty hard to analyze all aspects of a video recorded in the classroom, such as the moving image, in harmony with the voice, intonation, breaks and resumptions, the footage's angles are virtually impossible, because there is always some detail missing for good measure.

All the context is an attempt to make the visual material a source of research with unique features, through transcriptions and descriptions, since the video format is not provided to the reader. Thus, they produce not completely satisfying, but attractive and important outcomes, both written and oral, and the researcher is responsible to reduce such limitation with the technology advances (POWELL; FRANCISCO; MAHER, 2004).

Nevertheless, Garcez, Duarte e Eisenberg (2011) do not agree with the video footage's transcription. They believe that this kind of strategy is not appropriate, since a great part of the material's content and wealth is lost. So, they suggest the use of a technology resource, ATLAS. $\mathrm{ti}^{2}$, which enables a more original decoding.

In video analysis, Powell, Francisco and Maher (2004, p. 98, our translation) seek for "the development of mathematical ideas and reasoning as complex and non-linear

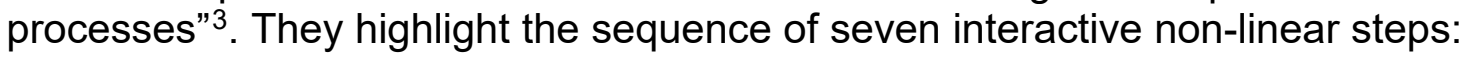
$\checkmark$ Data observation
$\checkmark$ Data description
$\checkmark$ Critical events identification ${ }^{4}$
$\checkmark$ Transcription
$\checkmark$ Coding
$\checkmark$ Arguments creation
$\checkmark$ Narrative composition

The observations and descriptions of videos provided the researchers with a range and a deep knowledge of their content, in which key situations (CARVALHO, 2004), or critical events (POWELL; FRANCISCO; MAHER, 2004) may be noted.

\footnotetext{
${ }^{2}$ ATLAS.ti is a professional software used for quantitative data analysis. Available in: https://atlasti.com.

3 "o desenvolvimento de ideias matemáticas e de raciocínio como processos complexos e não-lineares"

${ }^{4}$ For the authors, critical events is the identification of moments that are significant to the research.
} 
Hence, the analysis of this material allows the identification of critical events, keeping a relation with the subject under study, concerned with elaborating justifications or mathematical demonstrations (POWELL; FRANCISCO; MAHER, 2004).

\section{The importance of studies about learning, and mathematical justifications}

Learning in school mostly meets the requirements of a globalized and increasingly demanding society. In this regard, teachers always need to innovate their way of teaching, so they prepare the students to a better quality of life, and do not become enablers of neo-liberal policies (BEHRENS, 2006). The author believes that the teachers' and students' challenge is to always be in the process of learning how to learn, mostly as a result of the revolution imposed by technology in our society.

Therefore, the learning differs from the one that prevails in school environments, with lined students. It is necessary to leave behind the paradigm of knowledge transfer through memorization, based on the competition among students, encouraging the individuality (DEMO, 2010b; D’AMBROSIO, 2001).

However, Moran (2016) states that there are multiple ways to change the traditional classes, which can make sense to the learners. One of them is to invest in active learning to improve the learning. Watanabe, Baldoria and Amaral (2018) believe that the students must be the major players of their knowledge, so, it is necessary to provide them with new learning processes.

Undoubtedly, in order to create better conditions in these processes, there must be a practice grounded in an intellectual work of students and teachers, in addition to make political decisions, since rethinking the school is a matter of the State, but it does not exempt the school actors from reflecting about the reason of teaching Mathematics (SADOVSKY, 2010).

The school's excluding practice is to loosen the intellectual requirements up. It is expected that the students are not able to solve simple activities, such as applying rules, eliminating brackets in an exercise, and consequently, they cannot solve more complex problems (SADOVSKY, 2010).

Although, the teacher's view, with the teaching knowledge, helps to challenge the students to solve activities he/she believes to be complex, in order to dare, think and explore the interaction with the classmates (SADOVSKY, 2010).

Therefore, it is necessary to take into consideration that "the human mind operates on representations of the reality, which result from a mixture of observations, intuitions, previous experiences, and individual or collective memory" ${ }^{5}$ (D'AMBROSIO, 2001, p. 10 , our translation).

Hence, Sadovsky (2010) emphasizes that some proposals are very mechanized in Mathematics teaching, and because of this, they are not able to attract the students' interest to learn it, so, they are out of date and disconnected of the subject under

\footnotetext{
5 "a mente humana opera sobre representações do real, que são o resultado de um misto de observações, de intuições, de experiências prévias e de memória, individual e coletiva"
} 
discussion in class, which Sessa (2009) believes that creates simplification and algorithmization of the practices.

This mechanization is similar to memory repetition, represented in three ways: the first one is empirical, also known as the parrot effect, that is, when someone only repeats; the second is technical repetition, another way to say the same thing; and the last one is history repetition, which allows to historicize the subject's talk, making this speech fluent (ORLANDI, 2009).

\section{Methodology path}

This research is qualitative, a case study type, which, for Yin (2010), shows different ways of application, such as explanatory, descriptive and exploratory. Hence, this study presents an exploratory approach since its goal is to contribute to knowledge training with the arguments and justifications used by the students when solving the Math exercises.

For this research, 28 students of the $9^{\text {th }}$ year of Primary School, from a State School in an non-coastal city of São Paulo State, were invited to participate in videos footage that would be performed by the teacher during the discussion of the Math exercises solving on the blackboard.

The research was developed in two steps: in the first one, the teacher (one of the authors of this paper) proposed Math exercises from different materials, such as teaching books, and activities of the Ongoing Learning Assessment (AAP) ${ }^{6}$. In the second step, the Math exercised were chosen by the students, but the selected activities originated from the same sources as the first step.

A total of 10 videos was recorded. In this paper, we present and discuss four (4) videos footage: two from the first step, and the other two from the second one. All participants were voluntary, and there was no offer of grades or any compensations, thus enabling a different moment to study Mathematics.

Students were filmed by the teacher without any previous preparation or selection by the teacher. Their names will be represented by letters in the transcriptions of their speeches in the activities solving. The exercises were projected onto the screen by a multimedia projector, so that everyone had access to the question they were answering. In addition to this, the students used the blackboard to explain their answers.

\section{Description and comments of videos footage as an exploratory study in the classroom}

In step one, the students randomly decided which exercises they were going to solve. At first, they did not want to use the blackboard, and they were concerned, because the activity was different to them.

\footnotetext{
${ }^{6}$ AAP (Avaliação da Aprendizagem em Processo) is an assessment created by the Government of São Paulo State, which aims at evaluating the learning level of State Schools' students.
} 
They said that it was not just a correction of the exercises on the blackboard, and that the answer was not previously studied. Besides, the resolution would be filmed, which increased the stress, and reduced the researcher's contribution (POWELL; FRANCISCO; MAHER, 2004, HONORATO et al., 2006). The sequence took place with no interruptions, so patience was required, in order to get the first volunteer. There was no pressure, they had some time to think, and then the first request was made, but with much shyness.

The first student filmed was J., who accepted to participate. He wanted to do it because Math is his favorite subject, and because he has a great history in Olimpíadas de Matemática (Mathematics Olympic) ${ }^{7}$ in public school, with four bronze medals, and excellent grades in all the subjects. This video has 00:01:13.

The class was silent, showing their respect to their classmate, who explained how he had solved the exercise. During the recording, it was possible to hear noises from other classrooms. The proposed challenge was to find, among four numbers, which would be an irrational number. Board 1 shows this activity.

Board 1 - First exercise solved by the students.

Exercise 1. Only one of the four numbers below is an irrational number. Which one?
a) $\sqrt{\frac{1}{16}}$
b) $\sqrt{0,16}$
C) $\frac{1}{16}$
d) $\sqrt{1,6}$

Source: The authors (2020)

For his solution, J. explained:

My name is J., and I am going to solve this exercise:

Only one of the four numbers below is an irrational number. Which one? I will solve it by elimination. The first, $\sqrt{\frac{1}{16}}$ (root of one sixteenth) is $\frac{1}{4}$ (a quarter); every number written $\frac{a}{b}$ (a over b) is a rational number, so it cannot be this option. The second, $\sqrt{0.16}$ (root of zero point sixteen) is 0.4 (zero point four), so it is not an irrational number either. The third alternative, $\frac{1}{16}$ (one sixteenth) since here is written as $\frac{a}{b}$ (a over $b$ ), it is a rational number, $\underline{\text { so }}$ this is not the correct answer. Well, the only one left is the last option, $\sqrt{1.6}$ (square

\footnotetext{
${ }^{7}$ Olimpíadas de Matemática is an assessment created in 2005, in order to encourage the study of Mathematics, and to identify new talents.
} 
root of one point six), which is equal to $\sqrt{\frac{16}{10}}$ (sixteen over ten), square root of sixteen is 4 (four), $\frac{4}{\sqrt{10}}$, but 10 (ten) is not an exact square root, so this is the irrational number, alternative $d$.

As seen, student J. states he will "solve" it, not "try", which shows his confidence to solve the exercise. According to Sadovsky (2010), it is important to challenge the students to solve activities that for them are complex, but possible, since this will make them believe in their potential.

Student J. explained he would use the "elimination strategy", going over every alternative, and describing how he reached the correct answer, using terms like "that is" and "so", which, for Crowley (2003), are words used by teachers, depending on the student's level, which supports Orlandi's (2009) theory about the empirical repetition, when someone repeats speeches from the model they have as a reference, that is, the teacher in this case.

When establishing the rational number as a number in the format a over $b$, even though the definition of rational number is not complete, $\mathrm{J}$. is able to distinguish it from an irrational number, in alternative $\mathrm{d}$, by using the notation of a decimal number for the notation in fraction, and observing that the denominator in $\sqrt{\frac{16}{10}}$ does not have an exact square root. According to Borba (2006, p. 12, our translation), "[...] the difference between decimal and fractional notations in the rational numbers, and the multiplication and division operations in this range are difficult to be addressed in the school Mathematics"8.

Analyzing each alternative, J. reached the correct answer, and even though he presented some conceptual mistakes, he showed realm of the concepts used, fact possible to be observed in the video. The importance of using audiovisual resource is in the possibility of listening to it several times, and consequently being able to view in details how the students think in their definitions to seek the answer of an exercise, thus, it is a source of research about learning, theory supported by Powell and Silva (2015), and Borba and Oechsler (2018).

In the next video, with 00:01:09, student $A$. explained how to solve an exercise about scientific notation (Board 2). She seemed shy at first, but she had a great resourcefulness during the recording. Her behavior and the attitude of other shy students highlighted that using this resource, as described by Moran (1995), is important to allow the outgoing students to grant space, to open opportunities for the shy students to participate in the videos footage, with no need to worry about making mistakes, bringing complements from the classmates, without the usual jokes teenagers make.

The school has cameras inside all the classrooms, a decision made with support of the Board of School, and the Parent-Teacher Association (PTA). One justification for this action was the security of public assets, in order to create a culture that the school

8 "[...] a diferença entre a notação decimal e fracionária nos números racionais e a operação de multiplicação e divisão nesse conjunto são temas difíceis de serem tratados na Matemática escolar". 
is public and for everyone. Hence, students know they are filmed throughout the activities, which might have eased the work.

Board 2 - Second exercise solved by the students.

Exercise 2. In 1999, about 9,918,040 people lived in Portugal. Mark with (x) the number that approximately corresponds to this value.
a) $9,9 \cdot 10^{3}$
b) $9,9 \cdot 10^{4}$
c) $9.10^{5}$
d) $9,9 \cdot 10^{6}$

Source: The authors (2020)

Student A explained:

My name is A., I am in 9th year of Elementary School, and I will present the solution of this activity. In 1999, about 9,918,040 people lived in Portugal. Mark with $(x)$ the number that approximately corresponds to this value. First, we have to write the number of people: 9,918,040 (nine million, nine hundred eighteen thousand, and forty), and to solve it, we have to bring the point here in the beginning. Then, we take a number between one and ten, nine point nine (9.9), so, we just need to use the formula, which is times ten (10), and the power number is the quantity of numbers there is after the point, which is one, two, three, four, five and six. The result is $9,9 \times 10^{6}$. Alternative $d$.

In the transcription, A. showed she has a recipe to solve the exercise, which clearly demonstrate that she does not have a new way to solve it. Sadovsky (2010) and Demo (2010b) emphasize the importance of not having a mechanized process, since it might discourage the student. Post et al. (2003) believe that it is fundamental for the students to have a range of strategies to solve activities, in order to improve learning.

In step 2, the students chose the exercises to solve, and it was possible to note that they preferred the activities proposed in external assessments, over the ones in their usual materials. Some of them solved the exercise in pairs, they discussed and corrected each other.

Student R. solved a quadratic equation of incomplete type (Board 3).

Board 3 - Third exercise solved by the students.

Exercise 3. Classify equation $x^{2}+9=0$ regarding the solution.

a) The equation is valid and determined.

b) The equation is valid and undetermined.

c) The equation is not valid.

d) None of the previous alternatives is correct.

Source: The authors (2020)

The solution video has 00:00:44. The student took some time to decided whether he wanted to solve the activity, and after being encouraged by other students, he accepted the challenge. This student is quiet and very focused during classes. He explained: 
My name is $R$., and I am going to solve this equation here, which is $x$ squared plus nine, equal zero $\left(x^{2}+9=0\right) ; x$ squared equals nine negative, because it goes to the other side, and becomes negative $\left(x^{2}=-9\right) . x$ equals the squared root of nine negative $(x=\sqrt{-9})$, because the square goes to the other side as root. It does not exist in Real numbers ( $\nexists R$ ), because there is no square root; three times three equals nine $(3 \times 3=9)$, and three negative times three negative equals nine $((-3) \times(-3)=9)$, so the correct answer is alternative $c$, the equation is not valid.

R. simplified the term "go to", which Sessa (2009, p. 54, our translation) defines as "equate a problem and isolate an incognito (with all the corresponding rules)", showing in the student's speech a mechanized way to work on equations. Kieran (2003) states that when the student goes from the first to the second member using the inverse of each operation, in order to solve an equation, he causes the transposition generalization, which should be reviewed by the school if this process is overly emphasized, since it could indicate an inappropriate approach.

An important thing was that $R$. used the solution using another method, the replacement of values, to show that the value does not make the equation valid, so he turned to arithmetic to demonstrate why he could not find the solution.

This context is supported by Kieran (2003, p. 110, our translation), when he says that "[...] this type of experience at the Elementary School level could help to increase the capacity of a student initiating in algebra, in order to understand not only the solving procedures taught in High School, but also the equations" ${ }^{10}$.

Sessa (2009) states that it is important the student restricting "it does not exist in Real numbers $(\nexists R)$ ", because when he does not clarify the range, the students is able to make this connection, and consequently, limit the range the exercise can be solved in.

The fourth video has 00:00:48, showing student K. solving an exercise about the relation between height and age of a person, since the birth until the age of 50 (Board 4)

Board 4 - Fourth exercise solved by the students.

Question 4 - Over the life, growth is a very dynamic process, which happens up to the adulthood. The relation between a person's height and age, since the birth until the age of 50 , may be represented by charts. The chart of this function that represents this situation is:

\footnotetext{
9 "equacionar um problema e isolar uma incógnita (com todas as regras associadas)"

10 "[...] este tipo de experiência no nível da escola elementar poderia ajudar a aumentar a capacidade do aluno iniciante em álgebra para compreender não só os procedimentos de resolução ensinados no colegial como também as equações"
} 


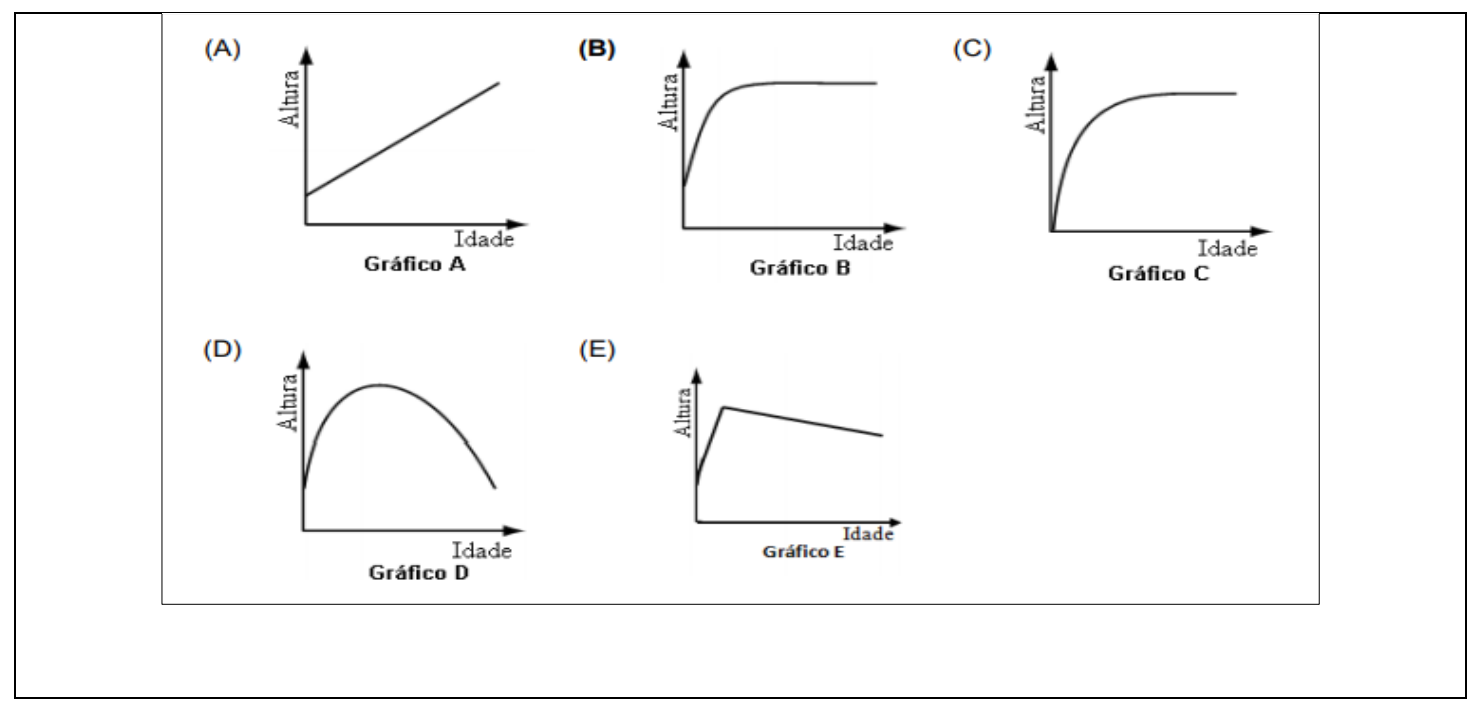

Source: AAP - 17th edition of Mathematics

Student K. explained:

I am student K. I am in 9th year of Elementary School, and I will solve this one. The chart can give us the relation between height and age of a person, since the birth until the age of 50. If you go follow my simple logic, which is quite complicated, there is no way the correct answer is alternative (A), because it only goes up, the height plus the age, neither this one, (C), because it is very small down here, and neither this ones, $(D)$ and $(E)$, because the person will not get shorter, so the correct answer is this one, (B), because the person is born with a certain height, and then the person grows and stops.

The student's answer did not have a recipe or a formula, but instead a solution that is not mechanized, which Sadovsky (2010) believes being important, so the student is interested in Mathematics. For K., her solution logic was simple, but complicated at the same time; analyzing each chart, she looked for a connection with her perception of a person's life cycle, since the birth until a certain age in adulthood. Hence, when she said, "because the person will not get shorter", it is possible to note that she used a representation of reality, which covers, according to D'Ambrósio (2001), the observations, intuitions and experiences, both individual and collective.

During her presentation, it was possible to notice some students' laughter, due to the way K. explained. She pointed to the projected screen and gesticulated, always being natural, and said why she chose that answer. So, for Borba and Oechsler (2018), it is possible to study the students' mathematics ideas when they express themselves orally, written and through gestures.

In all recordings, at the students' own initiative, they introduced themselves, and then identified the school, and read the proposed exercise. However, after some time, the class started ignoring the filming, and acting more naturally, following the activity development, giving opinions, helping and respecting the classmates. It is important to emphasize the way they interacted with their pairs.

\section{Final comments}


Using videos as a resource in order to study arguments and justifications that the students used to elaborate their reasoning for solving the proposed activities has shown to be an important means of analysis for teachers, in order to help them to review their teaching methods.

Presentations in the classroom were respected by the students, the environment had a great impact on their calm to solve the Mathematics exercises, interaction between the pairs was natural, and there was no need for any interference by the teacher.

The instruction class, using mechanical resolutions, still affects the way the students develop activities, which can highlight that the teacher often uses expository classes, and maintains the traditional work method. It is possible to identify, with the video footage, which words the students frequently use that are part of the vocabulary in books, or even of the teachers.

Is it fundamental to grant independence to the students, to review strategies, to use new resources, to give voice to whom learns and teaches, to know how to listen, to direct discussions, and to provide an appropriate environment to build and rebuild knowledge. Hence, school becomes part of the daily routine, in a way that contributes with the students' education.

\section{Bibliographic References}

BEHRENS, M. A. Projetos de aprendizagem colaborativa num paradigma emergente. In: MORAN, J. M. et al. Novas tecnologias e mediação pedagógica. 10th ed. Campinas: Papirus, 2006.

BORBA, M. C. Diversidade de questões em formação de professores de Matemática. In: BORBA, M. C. (Org.) Tendências internacionais em formação de professores de Matemática. Belo Horizonte: Autêntica, 2006. 140 p.

BORBA, M. C.; OECHSLER. V. Tecnologias na educação: o uso dos vídeos em sala de aula. Revista Brasileira de Ensino de Ciências e Tecnologia. Ponta Grossa, vol. 11, no. 2, p. 391-423, May/Aug. 2018.

CARVALHO, A. M. Metodologia de pesquisa em ensino de física: uma proposta para estudar os processos de ensino e aprendizagem. In: Encontro de Pesquisa em Ensino de Física, 9th ed., 2004, Jaboticatubas, MG. Anais... Jaboticatubas, MG: Sociedade Brasileira de Física, 2004.

CROWLEY, M. L. O modelo de Van Hiele de desenvolvimento do pensamento geométrico. In: LINDQUIST, M. M., SHULTE, A. P. (Org.) Aprendendo e ensinando geometria. 3rd ed. São Paulo: Atual, 2003.

D’AMBRosio, U. A matemática e os temas transversais (Prologue). São Paulo: Moderna, 2001.

DEMO, P. Aprendizagem no Brasil: ainda muito por fazer. 3rd ed. Porto Alegre: Mediação, 2010a. 96 p. 
DEMO, P. Ser professor é cuidar que o aluno aprenda. 7th ed. Porto Alegre: Mediação, 2010b, 88 p.

GARCEZ, A; DUARTE, R; EISENBERG, Z. Produção e análise de vídeogravações em pesquisas qualitativas. Educação e Pesquisa, São Paulo, vol. 37, no. 2, p. 249262, May/Aug. 2011.

HONORATO, A. et al. A vídeo-gravação como registro, a devolutiva como procedimento: pensando sobre estratégias metodológicas na pesquisa com crianças. In: Reunião Anual da Associação Nacional de Pós-Graduação e Pesquisa em Educação, 29, 2006, Caxambu. Anais..., Caxambu: ANPED, 2006.

KIERAN, C. Equações e expressões em álgebra: duas abordagens diferentes entre os principiantes em álgebra. In: Coxford, A. F.; Shulte, A. P. (Org.) As ideias da álgebra. São Paulo: Atual, 2003.

KRAMER, S. Autoria e autorização: questões éticas na pesquisa com crianças. Cadernos de Pesquisa. São Paulo, no. 116, p. 41-60, July, 2002.

MASETTO. M. T. Mediação pedagógica e o uso da tecnologia. In: MORAN, J. M. et al. Novas tecnologias e mediação pedagógica. 10th ed. Campinas: Papirus, 2006.

MORAN, J. M. O vídeo na sala de aula. Comunicação e Educação. São Paulo, vol. 1, no. 2, p. 27-35, Jan./Apr., 1995.

MORAN, J. M. Mudando a educação com metodologias ativas. In: Convergências midiáticas, educação e cidadania: aproximações jovens. Coleção Mídias Contemporâneas. 2015. Available in: http://www2.eca.usp.br/moran/wpcontent/uploads/2013/12/mudando_moran.pdf. Access on: April 5th, 2020.

MORAN, J. M. Por onde começar a transformar nossas escolas? In: MORAN, J. M. A Educação que desejamos: novos desafios e como chegar lá. Campinas: Papirus, 2016.

ORLANDI, E. P. Análise de Discurso: princípios \& procedimento. 8th ed. Campinas: Pontes, 2009. 100 p.

POST, A. F. et al. A proporcionalidade e o desenvolvimento de noções pré-álgebra. In: COXFORD, A. F.; SHULTE, A. P. (Org.) As ideias da álgebra. São Paulo: Atual, 2003.

POWELL, A. B.; FRANCISCO, J. M. E.; MAHER, C. A. Uma abordagem de análise de dados de vídeo para investigar o desenvolvimento das ideias matemáticas e do raciocínio de estudantes. Bolema, Rio Claro, no. 21, p. 81-140, 2004. 
POWELL, A. B.; SILVA, W. Q. O vídeo na pesquisa qualitativa em educação matemática: investigando pensamentos matemáticos de alunos. In: POWELL, A. B. (Org.) Métodos de pesquisa em educação matemática usando escrita, vídeo e internet. Campinas: Mercado de Letras, 2015, p. 15-60.

SADALLA, A. M.; LAROCCA, P. Autoscopia: um procedimento de pesquisa e de formação. Educação e Pesquisa, São Paulo, vol. 30, no. 3, p. 419-433, Sep./Dec. 2004.

SADOVSKY, P. O ensino de matemática hoje: enfoques, sentidos e desafios. 1. ed. São Paulo: Ática, 2010.

SESSA, C. Iniciação ao estudo didático da álgebra: origens e perspectivas. São Paulo: Edições SM, 2009.

TARDIF, M. Saberes docentes e formação profissional. 14th ed. Petrópolis, RJ: Vozes, 2012.

WATANABE, A.; BALDORIA, T.; AMARAL, C. L. C. O vídeo como recurso didático no Ensino de Química. Renote, Rio Grande do Sul, vol. 16, p. 1-15, 2018.

YIN, R. K. Estudo de caso: planejamento e métodos. Translation: Ana Thorell. Porto Alegre: Bookman. 2010.

\section{Received: $18 / 06 / 2020$}

Approved: $08 / 04 / 2021$

How to cite: OLIVEIRA, T. M. R.; AMARAL, C. L. C. Using video footage to analyze students' arguments in solving exercises: an experience in basic education. Revista de Estudos e Pesquisas sobre Ensino Tecnológico (EDUCITEC), v. 7, e133621, 2021.

\section{Authorship contribution:}

Terezinha Marisa Ribeiro de Oliveira - Conceptualization, data curation, research, methodology, writing, reviewing and editing

Carmem Lúcia Costa Amaral - Conceptualization, data curation, research, methodology, writing, reviewing and editing

Copyright: This article is licensed under the Creative Commons Attribution 4.0 International License.

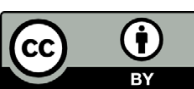

